\title{
УДК 616.981.553-07-035.7
}

\section{А.М. Сокол, А.С. Сидорчук, Ю.О. Рандюк, Н.А. Богачик, БОТУЛІЗМ: ДІАГНОСТИЧНІ ПОМИЛКИ В КЛІНІЧНІЙ ПРАКТИЦІ}

\section{Я.В. Венгловська, В.Д. Сорохан}

Буковинський державний медичний університет

Ключові слова: ботулізм, клініка, діагностичні помилки.

\begin{abstract}
Резюме. Проаналізовано серію клінічних помилок в діагностиці ботулізму. Увагу клініцистів акцентовано на типових симптомах i синдромах иієї хвороби, які, на жаль, подеколи залишаються поза увагою спеціалістів медичної практики різних спеціальностей. Водночас діагностичні помилки можуть "коштувати" життя не своєчасно пролікованих хворих спечифічними антиботулінічними сироватками.
\end{abstract}

Ботулізм в Україні відноситься до малопоширених інфекційних хвороб. Як правило, спостерігається спорадична захворюваність 3 поодинокими випадками в осередках. За даними МО3 України за період з 2009 по 2011 роки спостерігалося незначне зменшення захворюваності на ботулізм: в 2009 році діагностовано 123 випадки ботулізму, з них 7 осіб померло, в 2010 - 84 випадки, 3 них 2 особи померло та в 2011 - 83 випадки, з них 3 особи померло.

В інфекційному відділенні КУ "Обласна клінічна лікарня" в 2009 році перебували на стаціонарному лікуванні 6 осіб, в 2010 - 3 особи, в 2011 - 6 осіб, у 2012 - жодного хворого та у 2013 році троє хворих на ботулізм. У Чернівецькій області за останні 5 років було зареєстровано 18 хворих (1,9 на 100 тис. населення).

Смертельних випадків не було, але помилок у діагностиці спостерігалось чимало, не дивлячись на чітко окреслену клінічну картину цієї хвороби, яка в цілому характеризується паралітичним синдромом із залученням у патологічний процес різних відділів нервової системи.

На сучасному етапі клінічно виділяють наступні найважливіші синдроми:

- офтальмоплегічний синдром - суб'єктивно він проявляється порушенням зору ("туман", "сітка перед очима", "двоїння предметів"), а об'єктивно - птозом повік, мідріазом, збіжною чи розбіжною косоокістю, ністагмом, слабістю конвергенції;

- назоплегічний синдром суб'єктивно проявляється гугнявістю, носовим відтінком вимови, а об'єктивно - виливанням рідкої їжі через ніс, паралічем м'якого піднебіння, яке виявляють при ороскопії;

- фарингоплегічний синдром проявляється закашлюванням при намаганні проковтнути їжу в зв'язку з парезом чи паралічем надгортанника, що може зумовити попадання їжі в дихальні шляхи та асфіксію;

- ларингоплегічний синдром проявляється ознаками парезу чи паралічу голосових складок. Парез буде супроводжуватись охриплістю голосу, а параліч голосових складок - афонією.

Ці синдроми є найбільш ранніми і маніфестними в перебігу хвороби, оскільки вони повязані з ураженням черепномозкових нервів, і розуміння механізмів виникаючих порушень повинно б сприяти уникненню діагностичних помилок. На практиці ж помилки в діагностиці ботулізму найчастіше зумовлені якраз недооцінкою значень цих синдромів.

Так, при огляді окуліста, до якого, в першу чергу, й звертаються хворі у зв'язку з погіршенням зору, описуються, як правило, прозорість середовищ, деталі змін очного дна, особливо у пацієнтів похилого віку, але не оцінюється різниця в ширині очних щілин, результати перевірки реакції зіниць на світло, об'єм рухів очних яблук. У наших спостереженнях був випадок, коли окуліст спостерігав хворого на ботулізм упродовж тижня, а потім рекомендував йому обстеження в обласному діагностичному центрі, висловивши думку про "парез акомодації, можливо, інтоксикаційної етіології".

При обстеженні хворих на ботулізм лікаряминеврологами, як правило, встановлюється топічний діагноз - стовбуровий енцефаліт, але мова не йде про етіологію хвороби, тобто про ботулізм.

Непоодинокі випадки діагностичних помилок й у результаті неправильної оцінки лікарями інших суб'єктивних і об'єктивних симптомів. Так, наприклад, хвора скаржиться на утруднене ковтання, а лікар при огляді слизової оболонки ротової порожнини бачить виражену гіперемію (не звертає уваги на іï сухість), розцінює скаргу хворого як біль при ковтанні й діагностує ката- 
ральну ангіну. Гірше того, ми спостерігали випадок, коли хворий скаржився на утруднене дихання, а оториноларинголог при огляді "виявив стеноз гортані" (це при паралітичному синдромі), провів трахеотомію. Однак цей захід не покращив дихання хворого, бо воно було результатом ураження міжреберних нервів і відповідно, слабістю дихальної мускулатури. Крім того, пацієнт не міг самостійно мочитись, тому була накладена й епіцистостома. Ботулізм був діагностований лише на 7-й день хвороби.

Відомо, що бувають випадки, коли в початковій стадії ботулізму виникають симптоми ураження шлунково-кишкового тракту (біль у епігастральній ділянці, нудота, кількаразове блювання й короткочасний пронос), а через кілька годин чи днів з'являються типові симптоми ботулізму. Як правило, в цих ситуаціях діагностують гострі кишкові інфекції, харчову токсикоінфекцію, розцінюючи такі скарги, як сухість у роті, погіршення зору як результат зневоднення організму, не звертаючи уваги на відсутність клінічних симптомів порушення водноелектролітного балансу, (нормальний, а подеколи навіть підвищений артеріальний тиск, відсутність тахікардії, зниження тургору шкіри і т.п.), що характерно для "банальної" харчової токсикоінфекції. Так, за епідеміологією й патогенезом ботулізм належить до харчових токсикоінфекцій (на організм діє готовий ботулотоксин, який поступає в організм людини з харчовими продуктами), але, на відміну від харчових токсикоінфекцій, які викликаються токсинами стрептококів, стафілококів, умовно патогенної флори, захворювання на ботулізм не зумовлює відчутного зневоднення, а чинить вплив, насамперед, на нервову систему, порушуючи передачу нервових імпульсів з нервових закінчень на м'язові волокна [1].

Паралітична дія ботулотоксину може проявитись й ураженням міжреберних нервів, що призводить до дихальної недостатності різного ступеня аж до необхідності застосування штучної вентиляції легень.

Інколи говорять про атропіноподібну дію ботулотоксину (клінічно - сухість у роті, розширені зіниці, парез шлунка, сечового міхура, кишечнику 3 розвитком закрепів). Чим більш виражені ознаки дії ботулотоксину, тим тяжче перебігає хвороба, але ці симптоми треба активно виявляти цілеспрямованим опитуванням пацієнта та його вкрай ретельним об'єктивним обстеженням [2].

Важливою складовою діагностики ботулізму є епідеміологічний анамнез, перш за все з'ясування "харчового" анамнезу (терміном від кількох годин до 10 днів). Як правило, факторами передачі цієї інфекції є продукти домашнього консервування. Найчастіше ними виступають м'ясні консерви, консервовані паштети, рідше - рибні консерви, а також в'ялена риба.

Принагідно відмітити, що за останні роки істотно почастішали випадки ботулізму, при яких фактором передачі була саме вялена риба різної давності виготовлення, яка зберігалась за кімнатних умов. Акцентуація уваги на можливість участі харчів у передачі ботулотоксину, безумовно, зменшить число помилок у діагностиці ботулізму на догоспітальному етапі.

Сподіваємось, що наведені дані з особливостей перебігу ботулізму в сучасних умовах сприятимуть уникненню діагностичних помилок, покращать своєчасну діагностику й лікування цієї небезпечної хвороби.

Лiтература. 1. Bleck T. P. Clostridium botulinum. In: Mandell G.L., Bennett J.E., Dolin R., eds. Principles and practice of infectious diseases. 6 ed. New York: Churchill Livingstone - 2005. - P. 2822-2828. 2. Sobel J. Botulism / J. Sobel // Clin. Infect. Dis. - 2005. - Vol. 41 (8). - 1167-1173.

\section{БОТУЛИЗМ: ДИАГНОСТИЧЕСКИЕ ОШИБКИ В КЛИНИЧЕСКОЙ ПРАКТИКЕ}

А.М. Сокол, А.С. Сидорчук, Ю.А. Рандюк, Н.А. Богачик, Я.В. Венгловская, В.Д. Сорохан

Резюме. Проанализировано серию клинических ошибок в диагностике ботулизма. Внимание клиницистов акцентировано на типичных симптомах и синдромах этой болезни, которые, к сожалению, иногда остаются без внимания специалистов медицинской практики разных специальностей . Одновременно диагностические ошибки могут "стоить" жизни не своевременно пролеченных больных специфическими антиботулиническими сыворотками.

Ключевые слова: ботулизм, клиника, диагностические ошибки.

\section{BOTULISM: DIAGNOSTIC PITFALLS IN CLINICAL PRACTICE}

\section{A.M. Sokol, A.S. Sydorchuk, Yu.O. Randiuk, N.A. Bohachyk, Ya.V. Venglovska, V.D. Sorokhan}

Abstract. The series of clinical pitfalls in a diagnostics of botulism has been analyzed. Clinical attention is focused on a typical symptoms and syndromes of this infection, which, unfortunately, sometimes left unattended by medical practice professionals of different specialties. Simultaneously diagnostic errors could "cost" of life not timely treated sick by means of anti-botulinum specific sera.

Key words: botulism, clinics, diagnostics pitfalls.

Bukovinian State Medical University

Clin. and experim. pathol.- 2014.- Vol.13, №1 (47).-P.157-158. Надійшла до редакиії 03.03.2014 Речензент - проф. І.Й. Сидорчук

(ㄱ А.М. Сокол, А.С. Сидорчук, Ю.В. Рандюк, Н.А. Богачик, Я.В. Венгловська, В.Д. Сорохан, 2014 